\title{
CREATING A DIGITAL STORY OF BANTEN FOLKTALES FOR HIGHER EDUCATION STUDENTS
}

\author{
Yanti Anggraini $^{1}$, Rizky Wahyu Hadiyana ${ }^{2}$ \\ Politeknik PGRI Banten ${ }^{1,2}$ \\ yeongi09@yahoo.com, \\ risky.zs88@gmail.com
}

\begin{abstract}
The aims of this study were: (1) to discover the target needs of higher education students,

(2) to discover the learning needs of higher education students, and (3) to build-up a suitable digital story of Banten Folktales for higher education students. This was a Research and Development (R\&D) study. The research procedure, adjusted from ADDIE model proposed by Taylor (2004), comprised of conducting the needs analysis, designing a course grid and a storyboard, developing the first draft of the digital story, evaluating the first draft, and producing the final draft. The instruments to collect the data were needs analysis questionnaire and correspondent survey questionnaires. The information from the needs analysis was analyzed quantitatively using frequency and rate, and after that the comes about were utilized as the premise to create the course grid and storyboard. The quantitative data from the correspondent survey was analyzed through descriptive statistics while the comments and suggestions were used to revise the first draft to be the final product of the digital story. The developed product was valid and appropriate after being evaluated in correspondent review phase in terms of its content and design with the average score 4.69 categorized as very highly valid.
\end{abstract}

Keyword : R \& D research, digital story, local-content-based text, folktales

\section{INTRODUCTION}

$21^{\text {st }}$ century learning takes put in a quickly changing and technologysuffused environment. Key characteristics of this environment incorporate get to to an plenitude of data, expanded classroom accessibility of rising advances (e.g., portable learning gadgets, online applications, and social media devices), and the capacity to collaborate and contribute on an exceptional scale (Malita \& Martin, 2010; Robin, 2008). Looking for a cooperative energy of mechanical headways with advancements in instructional method, researchers have 
recommended that an perfect combination of technology-integrated learning and social constructivism is fundamental for achieving modern instructive destinations (Koohang, Riley, Smith, \& Schreurs, 2009; Neo \& Neo, 2010; Sadik, 2008).

A story could be a portrayal of occasions, individuals and places that a author or speaker describes in arrange to engage individuals. Undertakings, analyst and adore stories can moreover join shared legacy, teach and values giving the social education which is vital for progressing perusing comprehension (Rains, 2009). The power of stories has been welldocumented. Most social orders have socially interesting stories that have been passed down through the eras, in a few cases going back thousands of a long time. The control of stories is such that numerous anthropologists, analysts, and other researchers see it as being at the center of what makes us human. Perhaps not surprisingly, stories are also the oldest form of education (Reinders, 2011). Stories have been told as a way of passing on traditions, heritage and history to future generations. Indeed nowadays individuals proceed to tell stories through unused advanced media devices. A digital story can be seen as a merger between conventional narrating and the utilize of mixed media innovation (Normann, 2011).

Digital story is a useful teaching tool for not only second language learning but also for facilitating academic knowledge development of ELLs. Digital stories are not restricted to the individual story class and may be outlined to tie into students' scholastic aptitudes, cultivating the advancement of basic considering and media literacy (Ohler, 2008). Concurring to Robin (2008) cited in Dreyer (2017), digital story over the final few a long time has created as a capable instructing and learning instrument. It has the advantage of engaging both teachers and their students. Thinks about have appeared that the utilize of such a story viably progresses students' engagement within the learning process (Jenkins \& Lonsdale, 2007; Robin, 2008; Sadik, 2008 cited in Dreyer, 2017).

Abidin, Pour-Mohammadi, Souriyavongsa, Da and Ong (2011) examined the impacts of digital stories on the tuning in comprehension abilities of pre-school understudies in a foreign language learning context. In their research, the experimental group 
observed digital stories and a post-test appeared a noteworthy pick up over the control group. Sandaran and Lim (2013) conducted a research of the impacts of digital stories on listening comprehension abilities with 9-year old third grade in a Malaysian elementary school which utilized instruction in Chinese. Students listened and watched eight fairy stories outlined as digital stories. Preparatory discoveries gotten from perceptions appeared that the students' intrigued, concentration and inspiration expanded considerably, and their listening comprehension aptitudes created amid the listening exercises. In any case, they expressed that in arrange to create listening comprehension aptitudes, there ought to be vocabulary teaching exercises some time recently the students listened to and watched digital stories.

Regarding the use of local contents in ELT materials, there is a great support for their utilization as the materials in teaching English. Transmitting local cultures through the materials utilized in ELT in required as an endeavor of protecting national character (Petrus, 2012; Prastiwi, 2013). McKay (2003) contends that within the sense of English as an international language, the materials in ELT are not restricted as it were to the cultures of local English-speaking nations but ought to permit for local cultural substance.

Related to the explanation above, folklores initially from Banten can be utilized as reading materials in EFL teaching for students as an endeavor of protecting local personality so that the Banten folklores will travel from one era to the following era and will not be vanished from its presence as a part of the valuable cultures of Banten within the center of globalization threats. By including these Banten folklores as local-content-based texts in ELT materials, not only do students learn English but they also learn their own culture.

Based on the explanation given above, the purposes of this research were (1) to find out the target needs of higher education students, (2) to find out the learning needs of higher education students, and (3) to develop an appropriate digital story of Banten Folktales for higher education students. 


\section{METHOD}

The objective of this study is to develop an appropriate product that could be applied in the educational environment. Based on its purpose, this study is classified into Research and Development study. Research and Development ( $\mathrm{R} \& \mathrm{D})$ is an improvement show in which the discoveries of the inquire about are utilized to plan unused items and strategies, which are efficiently fieldtested, assessed, and refined until they meet indicated criteria of viability, quality, or comparative benchmarks (Gall, Gall, \& Borg, 2003).
Research procedure used in this study is ADDIE Design Model which is proposed by Taylor (2004) with some adaptation to meet the conditions of the research. Since the implementation stage is omitted in this research, revision stage then is added to complete the procedure. The scheme of the steps of the interactive learning multimedia development in this research is shown in figure below.

\section{Figure 1. Steps of Digital Story Development}

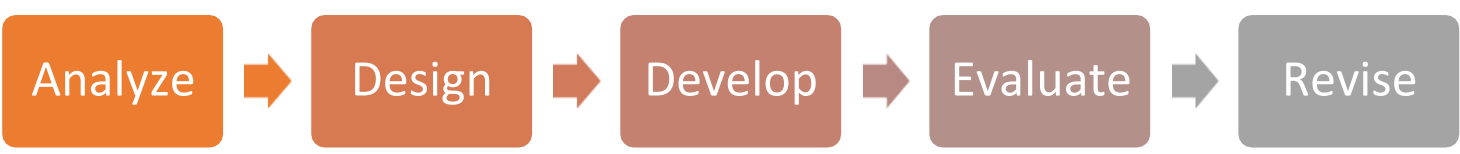


In Analysis Phase, the researcher analyzed the setting, the students' needs, and the materials. In Design Phase, the researcher designed a course grid based on the students' needs and created a storyboard to develop the digital story of Banten Folktales. In Development Phase, the digital story of Banten folktales was developed. In Evaluation Phase, after the digital story of Banten Folktales was developed then the researcher conducted correspondents' survey questionnaires. In Revision Phase, After the digital story of Banten Folktales has been evaluated then the researcher revised and produced the final draft of digital story of Banten Folktales.

The data collection technique used by the researcher in this study was questionnaire. There were two questionnaires used in this study. The first one was utilized in the needs analysis stage to get the data about students' target needs and learning needs. The second questionnaire was used in the correspondents' survey stage to substitute the field-testing stage. It was in order to get some suggestions, comments and validation about the final product. Then, the result of the data will be converted to descriptive analysis in terms of its goodness as proposed by Kubiszyn \& Borich (1993). 
Table 1. Data Conversion

\begin{tabular}{ccc}
\hline Average Score & & Category \\
\cline { 1 - 1 } $4.21-5.00$ & & Very High \\
$3.41-4.20$ & & High \\
$2.61-3.40$ & & Moderate \\
$1.81-2.60$ & & Low \\
$1.00-1.80$ & & Very Low \\
\hline
\end{tabular}

\section{DISCUSSION}

Analysis Phase

The students' needs analysis questionnaire was in the form of multiple choices questions and the highest percentage was considered as students' needs. The questionnaire covers the general description about the students' target needs and students' learning needs which deal with their preferences about the digital story.
1. Target Needs

Hutchinson and Waters (1987) state that target needs is what the learner has to do within the target circumstance whereas target circumstance relates to circumstances in which language is utilized. Target needs cover three perspectives which are: necessities, lacks, and wants. 
Table 2. The Results of Students' Target Needs

\begin{tabular}{crr}
\hline $\begin{array}{c}\text { Item } \\
\text { Number }\end{array}$ & The Highest Answers & Percentage \\
\hline $\begin{array}{c}\text { Necessities } \\
1\end{array}$ & $\begin{array}{l}\text { The students' motivation to learn English is } \\
\text { to be able to use English as a means of } \\
\text { communication both written and spoken } \\
2\end{array}$ & $\begin{array}{l}\text { The students' motivation to read English } \\
\text { texts } \\
\text { is to understand the texts }\end{array}$ \\
$\begin{array}{cl}\text { Lacks } \\
3\end{array}$ & $\begin{array}{l}\text { To the students, thing that cause difficulty to } \\
\text { read is English pronunciation }\end{array}$ \\
Wants & $\begin{array}{l}\text { Topics or themes of texts that the students } \\
4\end{array}$ & $38.46 \%$ \\
& like are legend
\end{tabular}

The results of students' target needs were: (1) students' motivation to learn English is to be able to use English as a means of communication both written and spoken; (2) students' motivation to read English texts is to understand the texts; (3) students' difficulty in reading English is pronunciation; (4) students mostly like a topic in reading is legend.

2. Learning Needs

Hutchinson and Waters (1987) make a refinement between target needs and learning needs. Learning needs are compared to the course of learning. This concerns things such as how learners learn the language, why they learn it and what assets are accessible to assist them learn. Learning needs are spoken to through a few components of assignment (Nunan, 2004) which are the input, the strategy, the teacher's role and the students' role. Included to this, the learning media and multimedia plan are too considered as students' learning needs. 
Table 3. The Results of Students' Learning Needs

\begin{tabular}{|c|c|c|}
\hline $\begin{array}{l}\text { Item } \\
\text { Number }\end{array}$ & The Highest Answers & Percentage \\
\hline \multicolumn{3}{|l|}{ Input } \\
\hline 4 & $\begin{array}{l}\text { The models of the English input text that the } \\
\text { students like are text with some pictures }\end{array}$ & $42.31 \%$ \\
\hline 6 & $\begin{array}{l}\text { The lengths of texts that students want are } \\
\text { about 300-500 words }\end{array}$ & $57.69 \%$ \\
\hline \multicolumn{3}{|c|}{ Procedure } \\
\hline 7 & $\begin{array}{l}\text { To enrich students' vocabulary, reading } \\
\text { activities they like the most are reading a text } \\
\text { then answering some questions related to the } \\
\text { text }\end{array}$ & $38.46 \%$ \\
\hline 8 & $\begin{array}{l}\text { To enrich students' knowledge about English } \\
\text { sentence structure, reading activity they like } \\
\text { the most is completing sentence with } \\
\text { available } \\
\text { words }\end{array}$ & $53.85 \%$ \\
\hline 9 & $\begin{array}{l}\text { The way the students preferred to do the } \\
\text { reading task is in small groups ( } 3-5 \text { students) }\end{array}$ & $42.31 \%$ \\
\hline 10 & $\begin{array}{l}\text { The technique of learning English that the } \\
\text { students preferred is engaging students in a } \\
\text { discussion }\end{array}$ & $42.31 \%$ \\
\hline
\end{tabular}




\begin{tabular}{|c|c|c|}
\hline \multicolumn{3}{|c|}{ Lecturer's Role } \\
\hline 11 & $\begin{array}{l}\text { According to the students, lecturers' role in } \\
\text { teaching English is explaining and giving } \\
\text { example on how to do the task }\end{array}$ & $53.85 \%$ \\
\hline \multicolumn{3}{|c|}{ Students' Role } \\
\hline 12 & $\begin{array}{l}\text { According to the students, their role in } \\
\text { learning English is engaging in the learning } \\
\text { activities actively }\end{array}$ & $88.46 \%$ \\
\hline \multicolumn{3}{|c|}{ Learning Media } \\
\hline 13 & $\begin{array}{l}\text { Students' preference of material sources is } \\
\text { internet }\end{array}$ & $46.15 \%$ \\
\hline \multicolumn{3}{|c|}{ Multimedia Design } \\
\hline 14 & $\begin{array}{l}\text { According to the students, the theme of } \\
\text { narrative text that the students want is things }\end{array}$ & $42.31 \%$ \\
\hline 15 & $\begin{array}{l}\text { The English teaching and learning media that } \\
\text { the students want are music or sound effects }\end{array}$ & $38.46 \%$ \\
\hline 16 & $\begin{array}{l}\text { Materials in learning English that the } \\
\text { students want is instruction and explanation } \\
\text { of clarified material }\end{array}$ & $50.00 \%$ \\
\hline 17 & $\begin{array}{l}\text { Background colors in digital story that the } \\
\text { students want are blue }\end{array}$ & $57.69 \%$ \\
\hline 18 & $\begin{array}{l}\text { Font of digital story that the students want is } \\
\text { Times New Roman }\end{array}$ & $69.23 \%$ \\
\hline 19 & $\begin{array}{l}\text { According to the students, the navigation } \\
\text { buttons of digital story should be simple and } \\
\text { easy }\end{array}$ & $38.46 \%$ \\
\hline 20 & $\begin{array}{l}\text { According to students, the availability of the } \\
\text { answer key in the digital story is needed }\end{array}$ & $46.15 \%$ \\
\hline
\end{tabular}

The results of students' learning needs were: (1) students' preference about the model text is dialogue or monologue; (2) the most preferable topics based on the students' view is legend; (3) students chose the input text that consists of 300-500 words; (4) reading a text followed by answering some questions related to the text is the students' preference; (5) reading activities that students preferred for enriching their knowledge about
English sentence structure is completing sentence with available words; (6) students preferred to do the reading task in small group; (7) the learning English techniques that are preferred by the students are when the lecturer engages the students in a discussion; (8) lecturer should explain and give example of how to do the task; (9) students' role in the learning activity is engaging in the learning activity actively; (10) students preferred internet as the material 
sources; (11) students wanted things as the themes of narrative text; (12) students wanted the availability of music or sound effect; (13) students wanted instruction and explanation of clarified material; (14) the best background color in the developed digital story is blue; (15) students chose Times New Roman as the font of contents in the developed digital story; (16) the navigation button of the developed digital story should be simple and easy; (17) students needed the availability of the answer key in the developed digital story.
Design Phase

In this phase, the first thing conducted was collecting all of folklores from Banten and were translated into English as the original folklores were in Indonesian. After being translated and adapted, the developed texts were checked to know their readability levels by using an online tool of Flesh Kincaid. The result is available in Table 2. In the reading materials, vocabulary knowledge in the form of synonym and antonym was also created.

Table 4. The Readability Level of the Folklores of Banten

\begin{tabular}{|c|c|c|c|c|}
\hline No & Title & $\begin{array}{l}\text { Readability } \\
\text { Level }\end{array}$ & Source & Remarks \\
\hline 1. & $\begin{array}{l}\text { Prince Pande Gelang and } \\
\text { Princess Cadasari }\end{array}$ & 4.3 & $\begin{array}{l}\text { Dinas } \\
\text { Perpustakaan }\end{array}$ & $\begin{array}{l}\text { Translated } \\
\text { and }\end{array}$ \\
\hline 2. & $\begin{array}{l}\text { The Legend of Lesung } \\
\text { Cape }\end{array}$ & 3.2 & $\begin{array}{l}\text { dan Arsip } \\
\text { Daerah (2019) }\end{array}$ & Adapted \\
\hline 3. & $\begin{array}{l}\text { The Legend of Mount } \\
\text { Pinang }\end{array}$ & 2.5 & & \\
\hline 4. & $\begin{array}{l}\text { The Legend of Karang } \\
\text { Bolong Beach }\end{array}$ & 7.2 & & \\
\hline 5. & The Origin of Cikaputrian & 3.6 & & \\
\hline 6. & $\begin{array}{l}\text { The Legend of Colored } \\
\text { Lake }\end{array}$ & 3.8 & & \\
\hline 7. & Geger Cilegon & 8.5 & & \\
\hline 8. & $\begin{array}{l}\text { The Legend of Munjul } \\
\text { Inscription }\end{array}$ & 6.2 & & \\
\hline 9. & $\begin{array}{l}\text { The Sacred Mosque of } \\
\text { Terate Udik }\end{array}$ & 4.4 & & \\
\hline 10. & $\begin{array}{l}\text { Sultan Maulana } \\
\text { Hasanuddin }\end{array}$ & 10.3 & & \\
\hline 11. & $\begin{array}{l}\text { The Legend of Kuwung } \\
\text { Stone }\end{array}$ & 6.8 & & \\
\hline
\end{tabular}




\begin{tabular}{llll}
\hline 12. & $\begin{array}{l}\text { The Legend of Mount } \\
\text { Santri }\end{array}$ & 13.4 & $\begin{array}{l}\text { Endang Firdaus } \\
(2004)\end{array}$ \\
13. & The Story of Leuwi Sero & 2.4 & \\
14. Kepuh Denok & 3.1 & $\begin{array}{l}\text { Endang Firdaus } \\
(2002)\end{array}$
\end{tabular}

Besides reading materials, the course grid was designed based on the students' needs as the guideline to develop and manage the tasks of the digital story. Core competences and standard competences also became consideration which underlay English teaching in higher education. Some materials and questions related to grammar learning were also added to complete the activities.

After all of the reading materials along with some activities had been completed, the materials were transformed into a digital story of Banten folktales. Thus, a storyboard was created to develop the developed digital story. The storyboard consisted of: (1) home slide; (3) learning objectives; (4) materials; (5) evaluation. All the paper-based designs consisting the materials were then transformed into computer-based design by using android system. The program was created and then launched in the form of application of digital story which could be run in PC or laptop.

\section{Development Phase}

After finding the results of the needs analysis and creating the course grid, the researcher then developed the digital story. The first draft of the digital story in this research presents two main parts: Home Page and Menu Page. Those two parts are described below.

\section{Home Page}

Home page is a starting screen of the digital story. When the digital story is operated then a list of Banten folktales appears. There are 14 stories that is available. 
Figure 2. Home Page
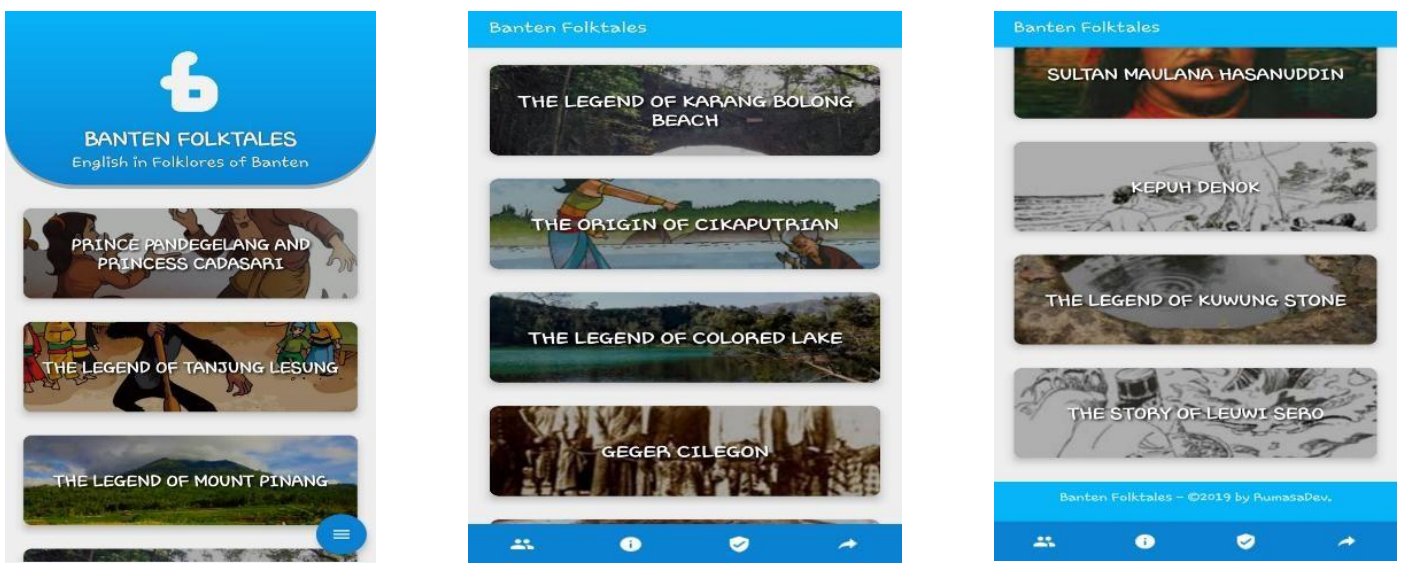

Besides a list of Banten folktales, there is a menu to know about the creators and objectives of the digital story was made.

\section{Figure 3. Names of The Creators}
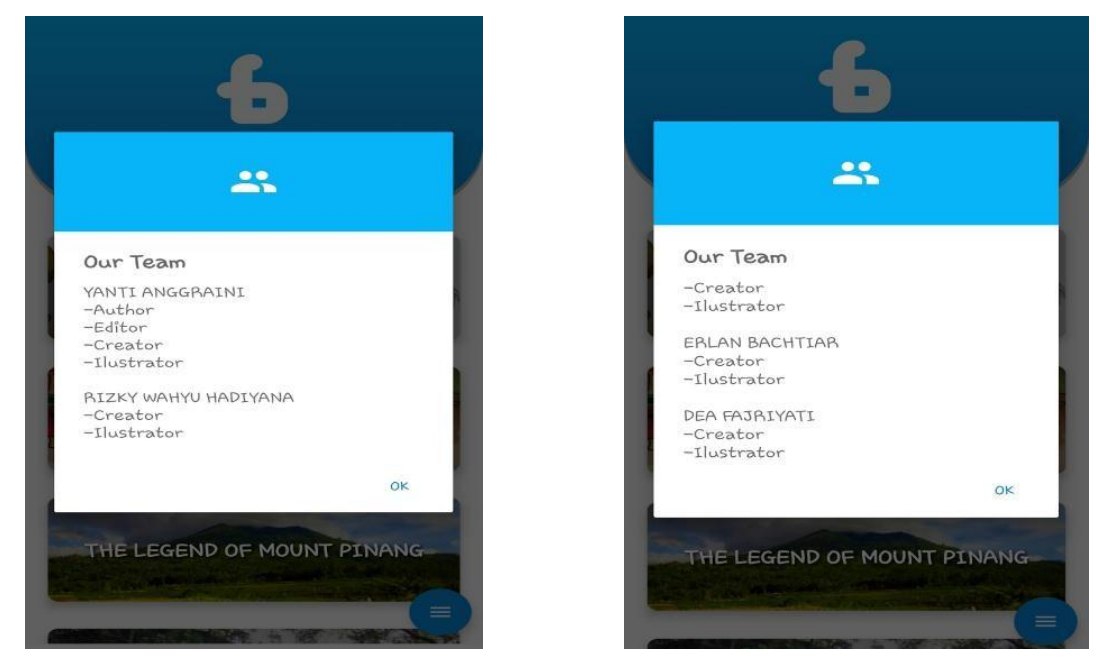


\section{Figure 4. The Objectives of The Developed Digital Story}
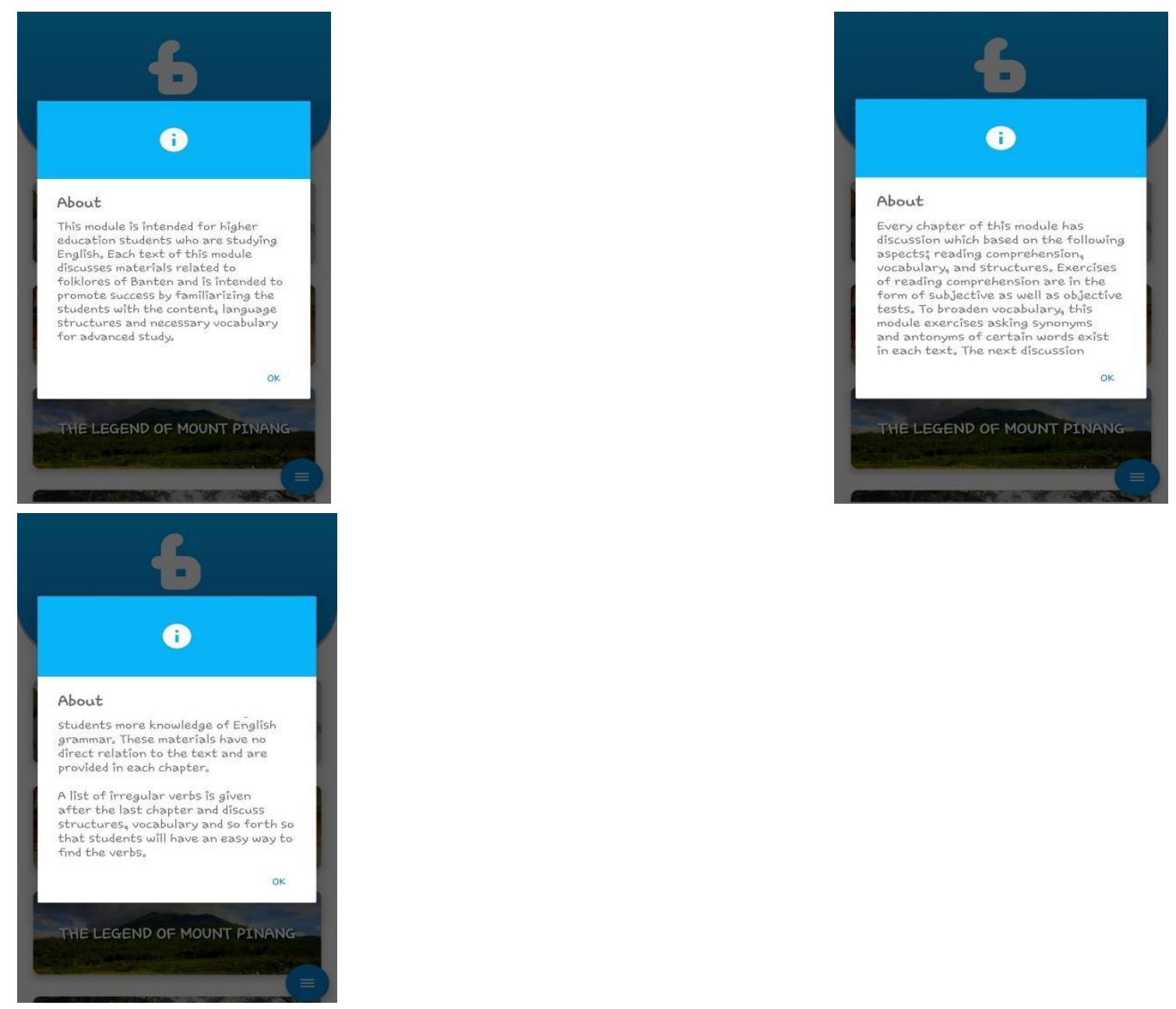

2. Menu Page

When students have clicked one of Banten folktales, there is a menu for learning objectives where there is a button, it is "Story". In menu "Story", students can learn about the story that has clicked by reading themselves or listening the audio that is available. There are some exercises for students that is also available. 


\section{Figure 5. Menu "Story" with Audio Listening}

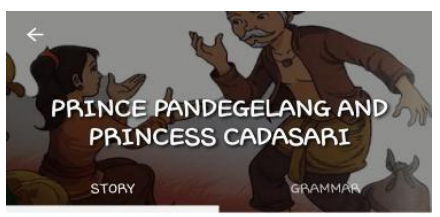

ONCE upon a time there was a kingdom of Banten. The king had a beautiful daughter. Hername was
Princess Cadasari. She was very beautiful and Princess Cadas
kind to people.

However, she was very sad lately. A prince from another kingdom came and planned to marry her.

hism he was arrown supernatural power. Prince Cunihin talked to the king about the marriage. The king accepted the proposal. He was afraid that Prince Cunihin would She did not have any cholce. She prayed to god. And in one night she had a dream. She was in the

On the following day, Princess Cadasari went to the hill and wated the handsome man. While she cher.
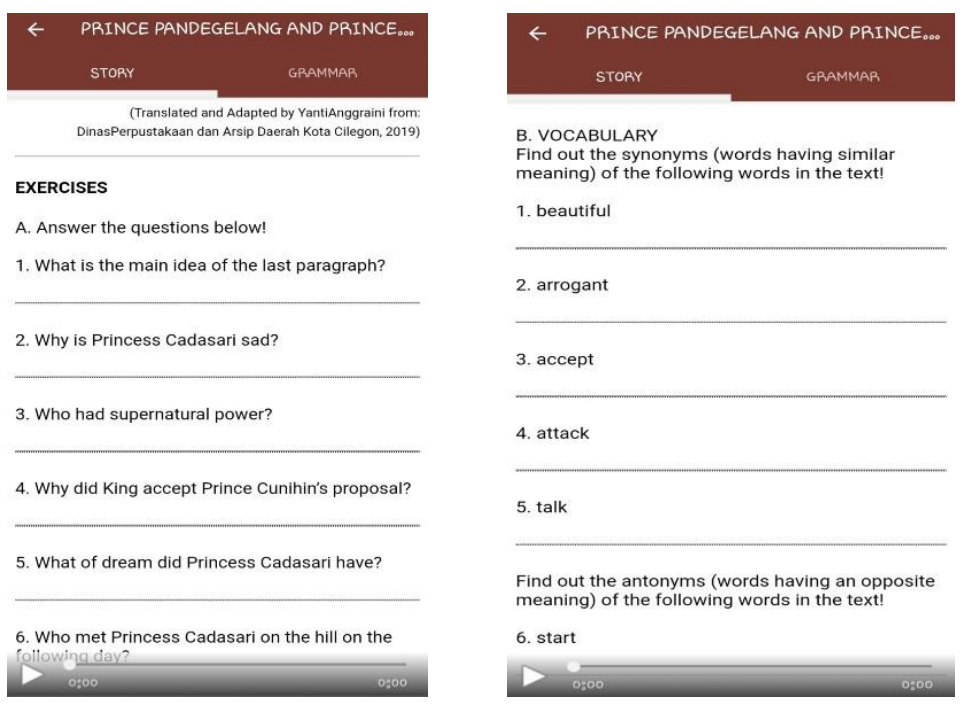

\section{Evaluation Phase}

After the first draft of the digital story had been developed, the next step is conducting correspondents' judgment to evaluate the appropriateness of the product in terms of its content and design. The instruments for the correspondent survey were two questionnaires related to the content and the design. As there were two questionnaires distributed, there were also two credible correspondents who evaluated the digital story in terms of the content and design. The correspondents were supposed to fill the questionnaires by choosing the options "SA" for strongly agree, "A" for agree,
"N" for neutral, "D" for disagree, and "SD" for strongly disagree. The results of the correspondent review questionnaires were then analyzed using descriptive statistics where the central tendency was employed to analyze the result and the average score was used as the measure of the tendency. The results of the correspondents' review are described below.

1) The Result of Content Aspects

In the first questionnaire, there are 25 statements categorized into three groups, which are content, language, and presentation. The results of digital story design evaluation are described below. 
Table 5. The Result of Correspondent Review towards Its Content Aspects

\begin{tabular}{|c|c|c|}
\hline $\begin{array}{c}\text { Item } \\
\text { Number }\end{array}$ & Statements & Score \\
\hline \multicolumn{3}{|c|}{ The Appropriateness of The Content } \\
\hline 1 & $\begin{array}{l}\text { Materials in the developed digital story are based on Lesson } \\
\text { Plan. }\end{array}$ & 5 \\
\hline 2 & $\begin{array}{l}\text { Materials in the developed digital story are in accordance with } \\
\text { Basic Competencies of Higher Education Students. }\end{array}$ & 4 \\
\hline 3 & $\begin{array}{l}\text { Materials in the developed digital story are appropriate for } \\
\text { learning activities. }\end{array}$ & 5 \\
\hline 4 & $\begin{array}{l}\text { Materials in the developed digital story are in accordance with } \\
\text { the learning objectives. }\end{array}$ & 5 \\
\hline 5 & $\begin{array}{l}\text { Examples and exercises are in accordance with the learning } \\
\text { objectives. }\end{array}$ & 5 \\
\hline 6 & $\begin{array}{l}\text { Materials in the developed digital story include the relevant } \\
\text { vocabulary. }\end{array}$ & 5 \\
\hline 7 & $\begin{array}{l}\text { Materials in the developed digital story contain reading sub- } \\
\text { skills activities. }\end{array}$ & 5 \\
\hline 8 & $\begin{array}{l}\text { Materials in the developed digital story include guidance related } \\
\text { to the comprehension of the text structure of the discussed text. }\end{array}$ & 5 \\
\hline 9 & $\begin{array}{l}\text { Materials in the developed digital story include guidance related } \\
\text { to the social function of the discussed text. }\end{array}$ & 4 \\
\hline 10 & $\begin{array}{l}\text { Materials in the developed digital story include guidance related } \\
\text { to the linguistic features of the discussed text. }\end{array}$ & 4 \\
\hline 11 & $\begin{array}{l}\text { Materials in the developed digital story include basic interactive } \\
\text { activities. }\end{array}$ & 5 \\
\hline 12 & $\begin{array}{l}\text { Learning elements (materials, exercises, and evaluation) have } \\
\text { appropriate amount. }\end{array}$ & 5 \\
\hline 13 & $\begin{array}{l}\text { Materials presented in the developed digital story are beneficial } \\
\text { for students' daily life. }\end{array}$ & 5 \\
\hline & Average Score & 4.77 \\
\hline \multicolumn{3}{|c|}{ The Appropriateness of The Language } \\
\hline 14 & $\begin{array}{l}\text { Instruction language used in the developed digital story is } \\
\text { correct and accurate. }\end{array}$ & 5 \\
\hline 15 & $\begin{array}{l}\text { Texts language used in the developed digital story can be } \\
\text { understood. }\end{array}$ & 5 \\
\hline 16 & $\begin{array}{l}\text { The materials in the developed digital story use English } \\
\text { grammatically. }\end{array}$ & 5 \\
\hline 17 & $\begin{array}{l}\text { The language used in instruction and explanation are relevant to } \\
\text { learners' language development. }\end{array}$ & 5 \\
\hline 18 & The materials in the developed digital story use correct spelling. & 4 \\
\hline 19 & $\begin{array}{l}\text { The materials in the developed digital story use correct the } \\
\text { words' choices. }\end{array}$ & 5 \\
\hline 20 & Grammar used in the developed digital story is correct. & 5 \\
\hline 21 & $\begin{array}{c}\text { Vocabulary used in the developed digital story is correct. } \\
\text { Average Score }\end{array}$ & $\begin{array}{c}5 \\
4.88\end{array}$ \\
\hline
\end{tabular}




\section{The Appropriateness of The Presentation}

22 Materials presented in the developed digital story are 5 systematically order.

23 Learning activities in the developed digital story help students to 5 be an autonomous learner.

24 The learning materials encourage the learners to learn 5 independently and to be responsible of their own learning process.

25 The learning materials encourage the learners to think and act creatively.

The table shows that the average score of the content appropriateness is 4.77. The score is in the range of $4.21<$ $\mathrm{x} \leq 5$ which falls into the "Very High" category.

From the result, it can be seen that the average score of the language appropriateness is 4.88 . The score is in the range of $4.21<\mathrm{x} \leq 5$ which falls into the "Very High" category.

The table shows that the average score of the presentation appropriateness is 5 . The score is in the range of $4.21<x \leq 5$ which falls into the "Very High" category.

It is concluded that the content aspects of the developed digital story are appropriate which most of each option has highest score.

2) The Result of Media Aspects

In the second questionnaire, there are 15 statements categorized into four groups, which are screen appearance, multimedia elements, navigation buttons, and feedback. The results of digital story design evaluation are described below. 
Table 6. The Result of Correspondent Review towards Its Media Aspects

\begin{tabular}{|c|c|c|}
\hline $\begin{array}{c}\text { Item } \\
\text { Number }\end{array}$ & Statements & Score \\
\hline \multicolumn{3}{|c|}{ The Appropriateness of The Screen Appearance } \\
\hline 1 & The screen appearance is clear. & 5 \\
\hline 2 & The screen appearance is proportional. & 5 \\
\hline 3 & $\begin{array}{l}\text { The colors combination used in the developed digital story is } \\
\text { compatible. }\end{array}$ & 4 \\
\hline 4 & $\begin{array}{l}\text { Pictures in the developed digital story supports learners in } \\
\text { understanding the materials better. }\end{array}$ & 4 \\
\hline 5 & Texts presented in the developed digital story are appropriate. & 4 \\
\hline 6 & Pictures presented in the developed digital story are appropriate. & 4 \\
\hline & Average Score & 4.33 \\
\hline \multicolumn{3}{|c|}{ The Appropriateness of The Learning Elements } \\
\hline 7 & $\begin{array}{l}\text { The type of font used in the developed digital story is } \\
\text { appropriate. }\end{array}$ & 5 \\
\hline 8 & $\begin{array}{l}\text { The size of font used in the developed digital story is not too big } \\
\text { and not too small. }\end{array}$ & 5 \\
\hline 9 & Texts, pictures, and animation are neatly arranged. & 4 \\
\hline & Average Score & 4.67 \\
\hline \multicolumn{3}{|c|}{ The Appropriateness of The Navigation Buttons } \\
\hline 10 & $\begin{array}{l}\text { The navigation buttons in the developed digital story are put in a } \\
\text { consistent way. }\end{array}$ & 4 \\
\hline 11 & $\begin{array}{l}\text { The navigation buttons in the developed digital story are easily } \\
\text { used. }\end{array}$ & 4 \\
\hline 12 & $\begin{array}{l}\text { The navigation buttons in the developed digital story are well } \\
\text { operated. }\end{array}$ & 4 \\
\hline 13 & $\begin{array}{l}\text { Shortcut to go back to the main menu and exit from the } \\
\text { application are available. }\end{array}$ & 4 \\
\hline & Average Score & 4 \\
\hline \multicolumn{3}{|c|}{ The Appropriateness of The Feedback } \\
\hline 14 & The developed digital story gives feedback directly. & 4 \\
\hline 15 & $\begin{array}{l}\text { Feedback helps users to operate the developed digital story } \\
\text { independently. }\end{array}$ & 5 \\
\hline & Average Score & 4.50 \\
\hline
\end{tabular}

The table shows that the average score of the screen appearance appropriateness is 4.33 . The score is in the range of $4.21<x \leq 5$ which falls into the "Very High" category. It shows that the clarity of the screen appearance, and the proportionally of the screen appearance have the highest score. Meanwhile the rest options are scored 4.

From the table it can be seen that the average score of the learning element appropriateness is 4.67 . The score is in 
the range of $4.21<\mathrm{x} \leq 5$ which falls

into the "Very High" category. It can be seen that the type of font and the size of font used in the developed digital story has the highest score in this aspect and the rest options are scored 4.

The table shows that the average score of the navigation buttons appropriateness is 4 . The value is in the range of $3.41<\mathrm{x} \leq 4.20$ which falls into the "High" category. It can be seen that all the options are scored 4.

The table shows that the average score of the feedback appropriateness is 4.50. The value is in the range of $4.21<$ 
$\mathrm{x} \leq 5$ which falls into the "Very High" category. It can be seen that the feedback button in the developed digital story has the highest score in this aspect and the rest options are scored 4.

It is concluded that the content aspects of the developed digital story are appropriate which most of each option has highest score.

\section{Revision Phase}

The average scores of all aspects of the content evaluation show that the materials are appropriate in terms of content, language, and presentation. First of all, in terms of content there is no specific suggestion proposed by the correspondent. The content is good and therefore needs no revision. The second, in terms of language is suitable for learners and there is no revision. Finally, in terms of presentation there is no weakness found and

needs no revision. Generally, the correspondent says that the developed digital story is good and interesting.

The average score of all aspects of the media evaluation show that the developed digital story is appropriate in terms of screen appearance, media elements, navigation buttons, and feedback. First of all, in terms of screen appearance there is no specific suggestion proposed by the correspondent. The screen appearance is good and therefore needs no revision. The second, in terms of media elements there is also no specific suggestion proposed by the correspondent. The media elements are good. The third, in terms of navigation buttons is good and there is no revision. The fourth, in terms of feedback there is also no revision. Generally, the correspondent says that the developed digital story is useful for learners.

It is concluded that there is no revision both content and media evaluation based on survey of correspondents. The final draft of the developed digital story was developed based on the feedback obtained from the correspondents' judgment. 


\section{Figure 6. The Final Draft of The Developed Digital Story}

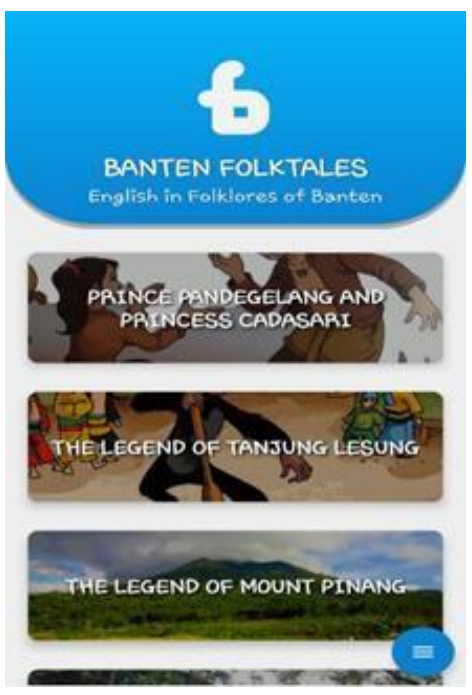

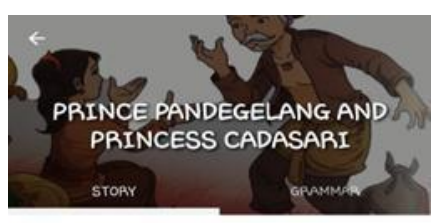

ONCE upon a time there was a kingdom of Banten. The king had a beautiful daughter. Hername was Princess Cadasari.
kind to people.

However, she was very sad lately. A prince from another kingdom came and planned to marry her His name was price cund heople dra not hike supernatural power. Prince Cunihin talked to the king about the marriage. The king accepted the proposal. He was afraid that Prince Cunihin would The marriage was set. Princess Cadasari was sad She did not have any choice. She prayed to god. hill and a hagdsome mad a dream.

On the following day, Princess Cadasari went to the hill and wated the handsome man. While she

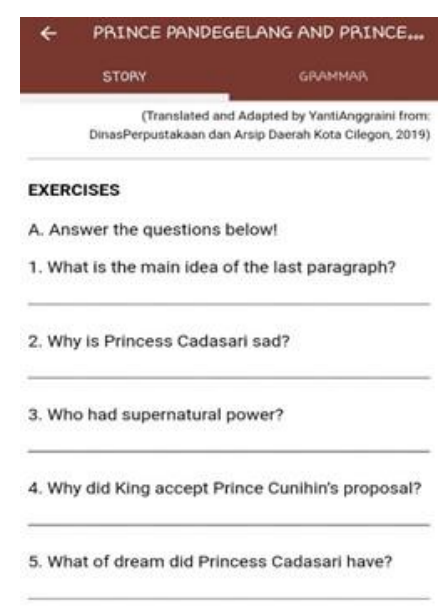

6. Who met Princess Cadasari on the hill on the 


\section{CONCLUSION}

Target Needs

It was found that the motivation of the research subject in learning English is to be able to use English as a means of communication both in spoken and written form. In relation to reading skill, they keep their motivation to read highly since they want to understand the text. However, they faced some difficulties while reading English text. Some of them is caused by pronunciation. The findings also show that the students' most favorite theme of the text is legend for local-contentbased text.

\section{Learning Needs}

The students' preferences related to the model of English input text are dialogue or monologue. Almost a half of the total number of the subject desired the texts that consist of 300-500 words. The most preferable topics based on the students' view is legend. Reading a text followed by answering some questions related to the text is the students' preference in learning the vocabulary. The students desired to learn the sentence structure by using explicit approach through a activity, such as completing sentence with available words. The students wanted to do the tasks in small group. Furthermore, the learning English techniques that are preferred by the students are when the lecturer engages the students in a discussion. Related to the lecturers' role, the students stated that the lecturer should give example of how to do the task. They were also fully aware that, during the learning activity, they should be engaged in the activities actively by doing the instruction. The internet was their most preferred media to learn English. Related to the content and design of the developed digital story, the students wanted to include music or sound effect inside it and also chose things as themes of narrative texts. Blue was the color they chose to be applied in the multimedia. According to them, the navigation buttons of the multimedia should be easy to find.

The Appropriate Digital Story for Teaching Narrative Text Reading

The appropriate digital story for teaching narrative text reading to higher education students had the following design.

1. Home Page

Home page is a starting screen of the digital story. When the digital story is operated then a list of Banten folktales appears. There are 14 stories that is available. Besides a list of Banten 
folktales, there is a menu to know about the creators and objectives of the digital story was made.

\section{Menu Page}

When students have clicked one of Banten folktales, there is a menu for learning objectives where there is a button, it is "Story". In menu "Story", students can learn about the story that has clicked by reading themselves or listening the audio that is available.

There are some exercises for students that is also available.

\section{ACKNOWLEDGEMENTS}

I extend deeply thanks to Ministry of Research, Technology and Higher Education of the Republic of Indonesia, Directorate General of Strengthening Research and Development,

Directorate of Research and Community Service that has funded this research in Implementation Year of 2019 in the Research of Beginner Lecturers (PDP). I also thank you to Journal of English Language Teaching and Literature (JELTL), Banten Jaya University has facilitated authors to present this paper as the form of national scientific journal output.

\section{REFERENCES}

Abidin, M. J. Z., Pour-Mohammadi, M., Souriyavongsa, T., Da, C. \& Ong, L. K. (2011). Improving listening comprehension among Malay preschool children using digital stories. International Journal of Humanities and Social Science, 1(14), 159-164.

Dinas Perpustakaan dan Arsip Daerah Kota Cilegon. (2019). Buku Cerita Rakyat. Cilegon: Dinas

Perpustakaan dan Arsip Daerah Dreyer, L. M. (2017). Digital storytelling to engage postgraduates in reflective practice in an emerging economy. South African Journal of Education, 37(4), 1-10.

Firdaus, E. (2002). Cerita Rakyat dari Banten 2. Jakarta: Penerbit Grasindo.

Firdaus, E. (2004). Geger Cilegon. Jakarta: Penerbit Grasindo.

Gal, M. D., Gal, J. P., \& Borg, W. R. (2003). Educational research: An introduction $7^{\text {th }}$ Ed. Boston, MA: Alyn and Bacon.

Koohang, A., Riley, L., Smith, T., \& Schreurs, J. (2009). E-learning and constructivism: from theory to application. Interdisciplinary 
Journal of Knowledge and Learning Objects, 5, 91-109.

Kubiszyn, T., \& Borich, G. (1993). Educational testing and measurement: Classroom application and practice. New York, NY: Harper Collins College Publisher.

Malita, L., \& Martin, C. (2010). Digital storytelling as web passport to success in the 21 st century.

Procedia-Social and Behavioral Sciences, 2(2), 3060-3064.

Neo, M., \& Neo, T. K.(2010).Students' perceptions in developinga multimedia project withina constructivist learning environment: a Malaysian experience. The Turkish Online Journal of Educational Technology, 9(1), 176-184.

Ohler, J. (2008). Digital storytelling in the classroom: New media pathways to literacy, learning, and creativity. Thousand Oaks, CA: Corwin.

Politeknik PGRI Banten. (2013). Buku panduan akademik Politeknik PGRI Banten. Cilegon: Politeknik PGRI Banten.

Rains, T. (2009). Using examples of myths stories in speaking.
Retrieved at

www.Ezinearticles.com.

Reinders, H. (2011). Digital storytelling in the foreign language classroom. Retrieved from http://blog.nus.edu.sg/eltwo/2011/ 04/12/digital-storytelling-in-theforeign language-classroom/

Sadik, A. (2008). Digital storytelling: a meaningful technology-integrated approach for engaged student learning. Educational Technology Research and Development, 56(4), 487-506.

Sandaran, S. C. \& Lim, C. K. (2013). The use of digital stories for listening comprehension among primary Chinese medium school pupils: Some preliminary findings. Jurnal Teknologi, 65(2), 125-131 
